\title{
Use of an Hfr Strain of E. coli for Prescreening of Antitumor antibiotics
}

\author{
Seiichi Tanida, Toru Hasegawa and Masahiko Yoneda \\ Microbiological Research Laboratories, Central Research Division, \\ Takeda Chemical Industries, 17-85, Juso-honmachi 2-chome, Yodogawa-ku, \\ Osaka 532, Japan \\ Received February 2, 1981
}

\begin{abstract}
An Hfr strain if Escherichia coli integratively suppressed by plasmid $\mathbf{F}$ showed high susceptibility to agents interacting with DNA at high temperature. Antitumor antibiotics, such as bleomycin, mitomycin $\mathrm{C}$, netropsin, and streptonigrin, which interact with DNA, and intercalating dyes, such as acriflavine, 9-aminoacridine and ethidium bromide, were active in assays of preferential activity against the growth of the $\mathrm{Hfr}$ strain at $42^{\circ} \mathrm{C}$. In the culture fluid of an actinomycete, dnacins, a new type of antibiotic interacting with DNA, were detected by this assay.
\end{abstract}

A large number of antitumor agents have the ability to interact with DNA and thus cause inhibition of DNA and/or RNA synthesis in tumor cells. ${ }^{1)}$ Efforts have been made to obtain such antitumor agents. ${ }^{2 \sim 4)}$ In our search for new antitumor antibiotics, we have employed an $\mathrm{Hfr}$ strain of $E$. coli made by integrative suppression. ${ }^{5)}$ The Hfr strain showed high susceptibility to various agents interacting with DNA at high temperatures. In an attempt to obtain active metabolites from the fermentation fluids of various kinds of actinomycetes isolated from natural sources, new aminobenzoquinoid antibiotics, dnacins, ${ }^{6,7)}$ were found. Further studies showed, as expected, that dnacins can interact with DNA molecules.

In this report, we examine whether the assay system with the Hfr strain can be employed to detect new antibiotics interacting with DNA, and discuss the validity of this system.

\section{MATERIALS AND METHODS}

Bacterial strains. An Hfr strain TE 120 and other control strains were derived from Escherichia coli CRT 46 whose mutation was temperature-sensitive during the initiation of DNA replication (dna A ts). ${ }^{5}$ ) For mating experiments, a multiple auxotrophic mutant AB 1157 (uvr $\mathrm{B}, t h r$, leu, thi, pro, his, arg, ara, lac, gal, xyl, mtl) was used as the recipient strain. For determination of curing activity, E. coli JE 2100 (W 3110 carrying R 100-1), JE 407 (W $3350 \mathrm{gal}^{-}$carrying $\mathrm{F}^{\prime}$ gal), and NAC-1 (NA-15) carrying $\mathrm{R} 100-1)$ were used as the test strains. The strains CRT 46, AB 1157, JE 2100, JE 407, and W $3110 \mathrm{~F}^{+}$were kindly provided by Dr. T. Iijima, Institute for Fermentation, Osaka, Japan.

Media. A medium containing $1 \%$ peptone, $0.5 \%$ yeast extract, $0.1 \%$ glucose, and $20 \mu \mathrm{g} / \mathrm{ml}$ thymine, $\mathrm{pH} 7.6$ was used for growth of the test strains. For plate assay, the medium was supplemented with $1.2 \%$ agar. Eosinmethylene blue (EMB) galactose plates contained $2.75 \%$ EMB base agar (Difco) to which $1 \%$ galactose was added for testing the fermentation of this sugar.

Assay. For broth assay, overnight cultures of test strains at $37^{\circ} \mathrm{C}$ with shaking were diluted 10 -fold with prewarmed fresh medium, and $50 \mu \mathrm{l}$ portions were added to the medium with varying concentrations of each agent. After 24 hours of incubation at $42^{\circ} \mathrm{C}$ or $32^{\circ} \mathrm{C}$ without shaking, growth was mesaured tubidimetrically (OD at $600 \mathrm{~nm}$ ) with a Hitachi spectrophotometer model 101. For plate assay, the overnight cultures were suspended in 100 parts of prewarmed medium. A $10 \mathrm{ml}$ portion of the suspension was poured into a plastic plate and solidified at room temperature. Paper discs with $20 \mu$ l samples were placed on duplicates of these plates. One of them was incubated at $42^{\circ} \mathrm{C}$, and the other at $32^{\circ} \mathrm{C}$. After 24 hours of incubation, the inhibition zone was measured.

Determination of curing activity. An overnight culture of E. coli JE 2100 , JE 407 or NAC-1 was diluted 1,000-fold with the medium and a $50 \mu \mathrm{l}$ portion of the diluent was added to $5 \mathrm{ml}$ of the medium containing varying concen- 
trations of dnacin $A_{1}$ or $B_{1}$, and shaken for 3 days at $37^{\circ} \mathrm{C}$. Colonies susceptible to chloramphenicol or with loss of ability for galactose fermentation in the survivors were counted as cured cells.

Chemicals. Chromomycin $\mathrm{A}_{3}$, cinerubin, enramycin, maridomycin, netropsin, sarkomycin, spectinomycin, streptonigrin, streptovaricin, sulbenicillin, tolypomycin, 5fluorouracil, and dnacins $A_{1}$ and $B_{1}$ were prepared in our research division. Actiomycin D, flavomycin, novobiocin, streptomycin, tetracycline and nalidixic acid were purchased from P-L Biochemicals Inc., USA. Also, the following inhibitiors were used; adriamycin (Kyowa Hakko Co., Japan), bleomycin (Nippon Kayaku Co., Japan), cephaloridine (Glaxo Labs., UK), chloramphenicol (Sankyo Co., Japan), colistin (Banyu Pharmaceutical Co., Japan), cycloserine (Sigma Chemical Co., USA), daunomycin (Meiji Seika Kaisha, Japan), erythromycin (Abbott Labs, USA), gentamicin (Schering Co., USA), kanamycin (Meiji Seika Kaisha, Japan), lincomycin (Upjohn Co., USA), mitomycin C (Kyowa Hakko Co., Japan), rifampicin (Ciba-Geigy Ltd., Switzerland), viomycin (Sigma Chemical Co., USA), acriflavine (Takeda Chemical Ind., Japan), 9-aminoacridine (Tokyo Chemical Ind., Japan), and ethidium bromide (Aldrich Chemical Co., USA).

\section{RESULTS}

\section{Isolation of test strains}

The properties of one Hfr strain TE 120 and several control strains are shown in Table I. TE 120 grew at $42^{\circ} \mathrm{C}$, was sensitive to male- specific coliphage MS2, caused a high frequency of recombination by mating with a female strain AB 1157, and showed high susceptibility to ethidium bromide at $42^{\circ} \mathrm{C}$. As shown in Fig. 1, the growth of TE 120 at $42^{\circ} \mathrm{C}$ was suppressed by $1.25 \mu \mathrm{g} / \mathrm{ml}$ of 9 -aminoacridine and $6.25 \mu \mathrm{g} / \mathrm{ml}$ of ethidium bromide, while four or more times of these agents was needed for inhibiting the growth of this strain at $32^{\circ} \mathrm{C}$. On the other hand, a control strain TE 144, a spontaneous temperature resistant revertant from CRT 46, did not show a marked difference in susceptibility to these agents between growth at $42^{\circ} \mathrm{C}$ and at $32^{\circ} \mathrm{C}$. Similar results were also obtained for another control strain TE 218 which is a male strain of TE 144 (data not shown)

\section{Establishing the screening system}

A screening system was established by the paper disc method at $42^{\circ} \mathrm{C}$ and $32^{\circ} \mathrm{C}$ using TE 120 and TE 144. Thirty kinds of antibiotics and five kinds of chemicals were tested in this assay system. As shown in Table II, some agents which interact with DNA, such as bleomycin, mitomycin $\mathrm{C}$, netropsin, and streptonigrin, ${ }^{1)}$ and intercalating dyes, such as acriflavine, 9-aminoacridine and ethidium bromide ${ }^{9,10)}$ showed preferential activity

Table I. Properties of the Strains

Plasmid F was introduced into CRT 46 or TE 144 by mating with $\mathrm{W} 3110 \mathrm{~F}^{+}$at $34^{\circ} \mathrm{C}$ for $60 \mathrm{~min}$. The isolated strains TE 217 and TE 218 were characterized by their susceptibility to male-specific coliphage MS2. The Hfr character was confirmed by mating with $\mathrm{AB} 1157$ as the recipient strain. Exponential cultures of donor and recipient strains were mixed at the ratio of $1: 9$, and incubated for $60 \mathrm{~min}$ at $34^{\circ} \mathrm{C}$ with gentle shaking. After interruption with vigorous agitation, the mixture was diluted 100 -fold with $0.05 \mathrm{~m}$ potassium phosphate buffer,

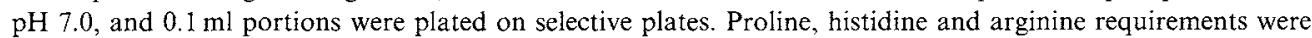
used as the selective markers. The susceptibility to ethidium bromide (EB) was measured with the liquid medium containing $10 \mu \mathrm{g} / \mathrm{ml}$ of this agent. After 24 hours of incubation at $32^{\circ} \mathrm{C}$ or $42^{\circ} \mathrm{C}$, growth was measured turbidimetrically.

\begin{tabular}{|c|c|c|c|c|c|}
\hline \multirow{2}{*}{ Strain } & \multirow{2}{*}{ Type } & \multicolumn{2}{|c|}{$+\mathrm{EB}$} & \multirow{2}{*}{$\begin{array}{l}-\mathrm{EB} \\
42^{\circ} \mathrm{C}\end{array}$} & \multirow{2}{*}{ Derivation } \\
\hline & & $32^{\circ} \mathrm{C}$ & $42^{\circ} \mathrm{C}$ & & \\
\hline CRT 46 & $\mathrm{~T} 46$ & + & - & - & \\
\hline TE 120 & $\mathrm{~T} 46 \mathrm{Hfr}$ & + & - & + & TE 217 \\
\hline TE 144 & $\mathrm{~T} 46^{\mathrm{r}}$ & + & + & + & CRT 46 \\
\hline TE 217 & $\mathrm{~T} 46 \mathrm{~F}^{+}$ & + & - & - & CRT 46 \\
\hline TE 218 & $\mathrm{~T} 46^{\mathrm{r}} \mathrm{F}^{+}$ & + & + & + & TE 144 \\
\hline
\end{tabular}

+ , growth; -, no growth. 


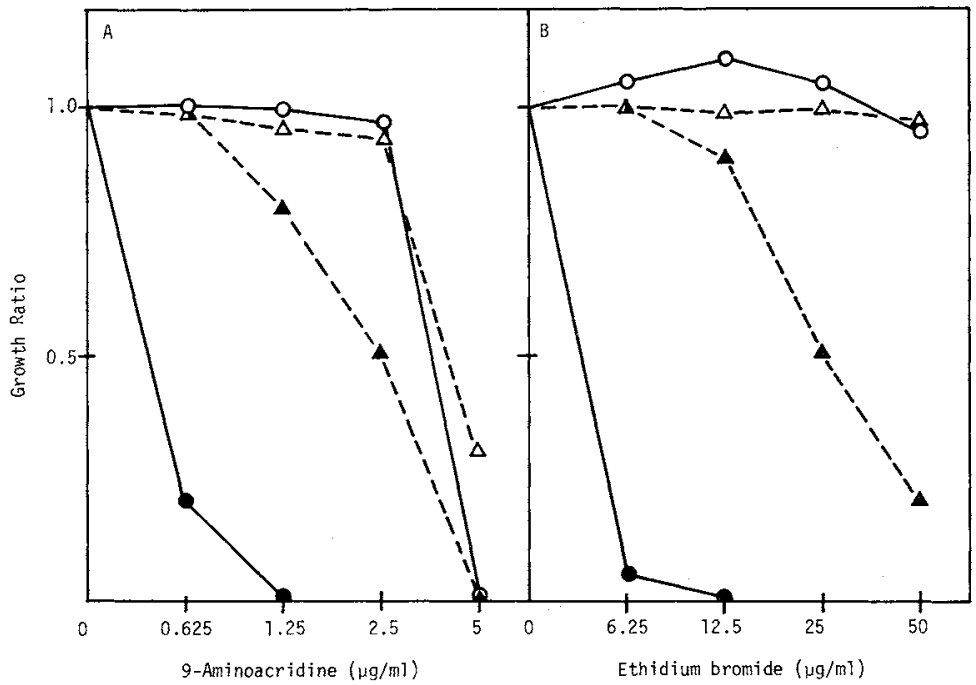

FiG. 1. Effect of Intercalating Dyes on Growth of TE 120 and TE 144.

The assay was carried out by the broth dilution procedures described in MATERIALS AND Methods. After 24 hours of incubation at $42^{\circ} \mathrm{C}$ or $32^{\circ} \mathrm{C}$, the turbidity of each culture was measured (OD at $600 \mathrm{~nm}$ ). The growth ratio was estimated relative to the turbidity of each drug-free culture.

O, TE 120 at $32^{\circ} \mathrm{C} ; 0$, TE 120 at $42^{\circ} \mathrm{C} ; \triangle$, TE 144 at $32^{\circ} \mathrm{C} ; \Delta$, TE 144 at $42^{\circ} \mathrm{C}$.

against TE 120 at $42^{\circ} \mathrm{C}$. However, actinomycin $D$, chromoycin $A_{3}$, and anthracycline antibiotics, such as adriamycin, daunomycin and cinerubin, which are known to bind to DNA strands resulting in interference with DNA and/or RNA synthesis in susceptible cells, ${ }^{1)}$ showed no activity in this assay system. Various kinds of actinomycetes isolated in our laboratories were cultivated to search for active metabolites in the culture fluids of microorganisms. Among strains tested, we found that Nocardia sp. No. C-14919 (N-1001) had the ability to produce active metabolites which were new aminobenzoquinoid antibiotics and named dnacins. Details on dnacins have been described in previous reports. $^{6,7)}$

\section{Curing activity of dnacins}

Dnacins showed preferential activity against the Hfr strain at a high temperature in an aqueous condition. As shown in Fig. 2, dnacins $A_{1}$ at $0.1 \mu \mathrm{g} / \mathrm{ml}$ and $B_{1}$ at $0.05 \mu \mathrm{g} / \mathrm{ml}$ suppressed TE 120 growth at $42^{\circ} \mathrm{C}$, whereas twice the amount of each component did not markedly affected the growth of TE 144 at this temperature. These results suggest that dnacins show preferential activity against the replication machinery of F-like plasmids at effective concentrations. This was supported by the results on the curing experiments. As shown in Fig. 3B, dancin $B_{1}$ at 0.01 to $0.05 \mu \mathrm{g} / \mathrm{ml}$ caused a high frequency of plasmid loss from $\mathrm{R} 100-1$ or $\mathrm{F}^{\prime}$ gal bearing strains without affecting the growth of host cells. Similar results were also obtained by using dnacin $A_{1}$ at 0.05 to $0.1 \mu \mathrm{g} / \mathrm{ml}$ (Fig. 3A).

\section{DISCUSSION}

Nishimura et al. ${ }^{5)}$ reported that a bacterial mutant which is temperature sensitive to the initiation of DNA replication (dna A ts) can be suppressed by an integrated plasmid $F$ and related replicons, and they called this phenomenon "integrative suppression." This phenomenon indicates that such bacterial mutant can replicate its chromosome by employing the replication machimery of the integrated plasmid at a restrictive temperature. Such $\mathrm{Hfr}$ strains showed high susceptibility to intercalating dyes at $42^{\circ} \mathrm{C} .{ }^{5,11}$ ) As shown in this 
TABLE II. ACTIVITY OF Various Agents

\begin{tabular}{|c|c|c|c|c|c|}
\hline \multirow{2}{*}{ Agent } & \multicolumn{3}{|c|}{ Activity $^{a}$} & \multirow{2}{*}{$\begin{array}{c}\text { Interaction }^{b} \\
\text { with DNA }\end{array}$} & \multirow{2}{*}{$\begin{array}{l}\text { Antitumor } \\
\text { activity }\end{array}$} \\
\hline & 20 & 2 & $0.2 \mu \mathrm{g} / \mathrm{disc}$ & & \\
\hline Actinomycin D & - & - & - & + & + \\
\hline Adriamycin & - & - & - & + & + \\
\hline Bleomycin & \pm & \pm & - & & \\
\hline Cephaloridine & - & - & - & & \\
\hline Chloramphenicol & - & - & - & & \\
\hline Chromomycin $\mathrm{A}_{3}$ & - & - & - & + & + \\
\hline Cinerubin & - & - & - & + & + \\
\hline Colistin & - & - & - & & \\
\hline Cycloserine & - & - & - & & \\
\hline Daunomycin & - & -- & - & + & + \\
\hline Enramycin & - & - & - & & \\
\hline Erythromycin & - & - & - & & \\
\hline Flavomycin & - & - & - & & \\
\hline Gentamycin & - & - & - & & \\
\hline Kanamycin & - & - & - & & \\
\hline Lincomycin & - & - & - & & \\
\hline Maridomycin & - & - & - & & \\
\hline Mitomycin C & nt & $\mathrm{nt}$ & + & + & + \\
\hline Netropsin & + & + & - & + & + \\
\hline Novobiocin & - & - & - & & \\
\hline Rifampicin & \pm & - & - & & \\
\hline Sarkomycin & + & - & - & & + \\
\hline Spectinomycin & - & - & - & & \\
\hline Streptomycin & - & - & - & & \\
\hline Streptonigrin & $\mathrm{nt}$ & + & \pm & + & + \\
\hline Streptovaricin & - & - & - & & + \\
\hline Sulbenicillin & - & - & - & & \\
\hline Tetracycline & - & - & - & & \\
\hline Tolypomycin & - & - & - & & \\
\hline Viomycin & - & - & - & & \\
\hline Acriflavine & $\mathrm{nt}$ & + & \pm & + & \\
\hline 9-Aminoacridine & $\mathrm{nt}$ & + & \pm & + & \\
\hline Ethidium bromide & + & \pm & - & + & \\
\hline 5-Fluorouracil & - & - & - & & + \\
\hline Nalidixic acid & - & - & - & & \\
\hline
\end{tabular}

a The activity was measured by the paper disc method described in MATERIALS AND METHODS, and indicated by the difference between inhibition zone $\left(a t 42^{\circ} \mathrm{C}-\right.$ at $32^{\circ} \mathrm{C}$ ) of TE 120 and that of TE $144:+,>5 \mathrm{~mm} ; \pm, 3$ to $5 \mathrm{~mm} ;-,<3 \mathrm{~mm} ; \mathrm{nt}$, not tested.

$b$ Fuska and Proksa, ref. 1; Nishimura et al., ref. 5.

c Fuska and Proksa, ref. 1 .

report, agents which have the ability to interact with DNA are efficiently detected by a system that uses an Hfr strain made by integrative suppression. However, some antibiotics, such as actinomycin $\mathrm{D}$, chromomycin $\mathrm{A}_{3}$ and anthracyclines did not show any remarkable activity, in spite of their ability to react with DNA. ${ }^{1)}$ This relative inactivity may be due to the permeability barrier of the test strain to these antibiotics. Although rifampicin, a specific inhibitor of bacterial DNAdependent RNA polymerase, ${ }^{12)}$ does not interact with DNA, it showed a slight effect in this assay system. Since there are some reports on the curing activity of rifampicin to plasmids, ${ }^{9,13)}$ the activity of rifampicin in this system may be caused by a similar mechanism of action of this antibiotic to plasmid DNA 


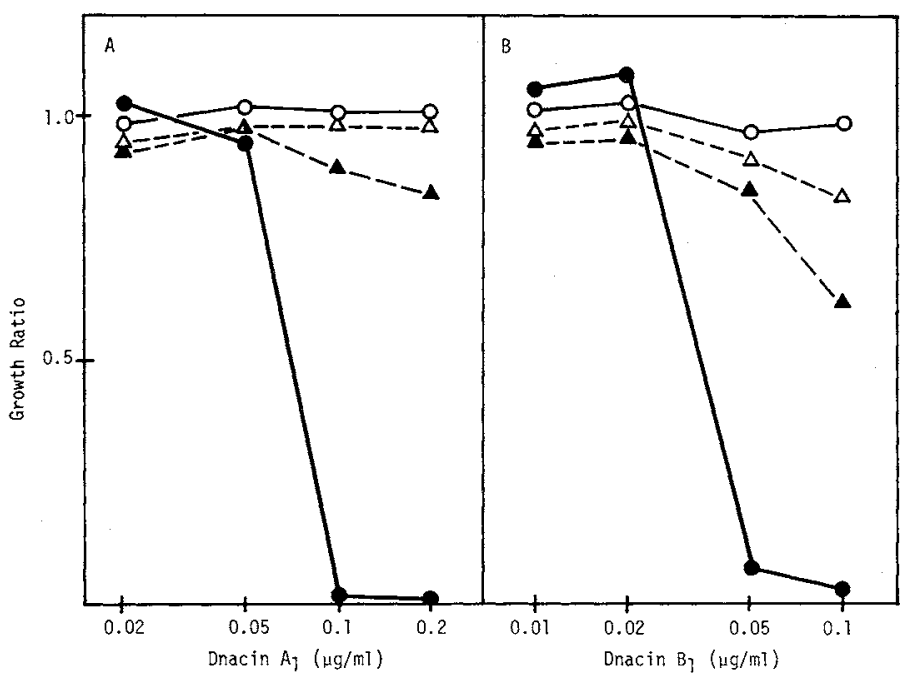

FIG. 2. Effect of Dnacins on Growth of TE 120 and TE 144.

The assay was carried out by the procedures described in MATERIALS AND METHODS. Symbols used are the same as in Fig. 1.

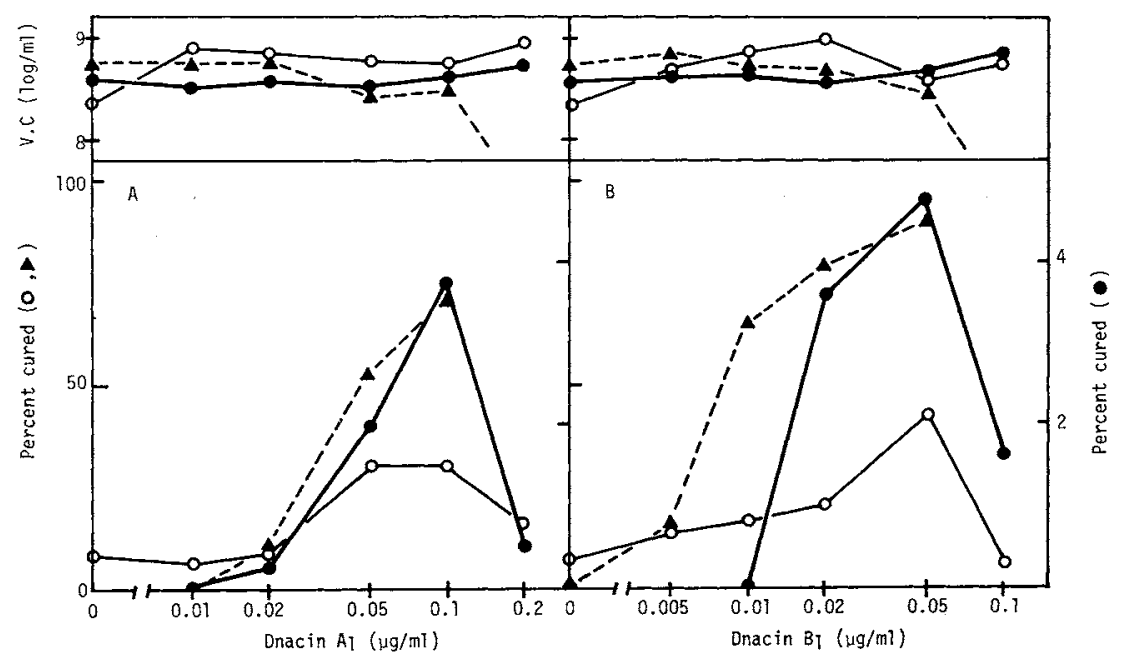

FIG. 3. Curing Activity of Dnacins.

Plasmid-bearing strains of $E$. coli were cultured for 3 days with varying concentrations of dnacin $A_{1}$ or $B_{1}$. These cultures were diluted and plated on selective plates. Susceptibility of more than 200 colonies of JE 2100 or NAC-1 picked at random was tested on a plate containing $20 \mu \mathrm{g} / \mathrm{ml}$ of chloramphenicol. The ability for galactose fermentation of more than 350 colonies of JE 407 was tested on EMB galactose plates. The numbers of colonies susceptible to chloramphenicol or with loss of ability for galactose fermentation are indicated as percent cured.

A, JE $2100 ;$ O, JE 407; O, NAC-1.

$\mathrm{VC}$, viable cells.

replication. The validity of this assay system was supported by the finding of the new antibiotics, dnacins. ${ }^{6,7)}$ As was expected, dnacins have the ability to cause a high frequency of loss of F-like plasmids, probably due to their reactivity with plasmid DNA. Moreover, dancins have the ability to interact with DNA molecules in vitro (data will be published 
elsewhere), and the property of prolonging the life span of leukemia P388-bearing mice (Ootsu, unpulished data).

Acknowledgments. We wish to thank Dr. T. Iijima for his kind gift of bacterial strains. We also thank Drs. E. Higashide, M. Asai and M. Muroi for their valuable discussion, and Mr. Y. Nakano for his technical assistance.

\section{REFERENCES}

1) J. Fuska and B. Proksa, Adv. Appl. Microbiol,, 20, 259 (1976).

2) S. Mong, J. E. Strong, J. A. Bush and S. T. Crooke, Antimicrob. Agents Chemother., 16, 398 (1979).

3) J. Le Pecq, N. D. Xuong, C. Gosse and C. Paoletti.,
Proc. Natl. Acad. Sci. USA, 71, 5078 (1974).

4) K. W. Kohn, Methods Cancer Res., 16, 291 (1979).

5) Y. Nishimura, K. Caro, C. M. Berg and Y. Hirota, J. Mol. Biol., 55, 441 (1971).

6) S. Tanida, T. Hasegawa, M. Muroi and E. Higashide, J. Antibiot., 33, 1443 (1980).

7) M. Muroi, S. Tanida, M. Asai and T. Kishi, J. Antibiot., 33, 1449 (1980).

8) S. Tanida, T. Hasegawa, T. Yamano and $M$. Yoneda, J. Antibiot, 29, 754 (1976).

9) F. E. Hahn, Antibiot. Chemother., 20, 196 (1976).

10) F. E. Hahn, Naturwissenschaften, 66, 555 (1979).

11) M. Yoshikawa, Antimicrob. Agents Chemother., 5, 362 (1974).

12) W. Wehrli and M. Staehlin, Bacteriol. Rev., 35, 290 (1971).

13) P. Bazzicalupo and G. Tocchini-Valentini, Proc. Natl. Acad. Sci. USA, 69, 298 (1972). 